Hoof: Lysosomes and Storage Diseases, p. 453 (Academic Press, New York, 1973).

20. Patrick, A. D., Willcox, P., Stephens, R., and Kenyon, V. G.: Prenatal diagnosis of Wolman's disease. J. Med. Genet., 13: 49 (1976).

21. Peters, T. J., Takano, T., and DeDuve, C.: In: R. Porter and J. Knight: Atherogenesis, Initiating Factors, Ciba Foundation Symposium 12, p. 197 (Elsevier, Amsterdam, 1973).

22. Raafat, R., Hashemian, M. P., and Abrishami, M. A.: Wolman's disease: Report of two new cases with a review of the literature. Amer. J. Clin. Pathol., 59: 490 (1973).

23. Rattazzi, M. C., Brown, J. A., Davidson, R. G., and Shows, T. B.: Tay-Sachs and Sandhoff-Jatzkewitz diseases: Complementation of $\beta$-hexosaminidase deficiency by somatic cell hybridization. Amer. J. Hum. Genet., 26: 71 A (1974).

24. Schotz, M. C. Garfinkel, A. S., Huebotter, R. J., and Stewart, J. E.: A rapid assay for lipoprotein lipase. J. Lipid Res., 11: 68 (1970).

25. Sloan, H. R., and Fredrickson, D. S.: Rare familial diseases with neutral lipid storage; Wolman's disease, cholesteryl ester storage disease and cerebrotendinous xanthomatosis. In: J. B. Stanbury, J. B. Wyngaarden, and D. S. Frederickson: The Metabolic Basis of Inherited Disease, Ed. 3, p. 808 (McGrawHill, New York, 1972).

26. Sloan, H. R., and Fredrickson, D. S.: Enzyme deficiency in cholesteryl ester storage disease. J. Clin. Invest., 51: 1923 (1972).

27. Takano, T., Black, W. J., Peters, T. J., and DeDuve, C.: Assay, kinetics and lysosomal localization of an acid cholesteryl esterase in rabbit aortic smooth muscle cells. J. Biol. Chem., 249: 6732 (1974).

28. Thomas, G. H., Taylor, H. A., Miller, C. S., Axelman, J., and Migeon, B. R.: Genetic complementation after fusion of Tay-Sachs and Sandhoff cells. Nature, 250: 580 (1974)

29. Uno, Y., Taniguchi, A., and Tanaka, E.: Histochemical studies in Wolman's disease-Report of an autopsy case accompanied with a large amount of milky ascites. Acta Path. Jap., 23: 779 (1973).

30. Wallis, K., Gross, M., Kohn, R., and Zaidman, J.: A case of Wolman's disease. Helv. Paediat. Acta, 26: 98 (1971)

31. Wolf, H., Hug, G., Michaelis, R., and Nolte, K.: Seltene, angeborene Erkrankung mit Cholesterinester-Speicherung in der Leber. Helv. Paediat. Acta, 29: 105 (1974).

32. Wolman, M., Sterk, V. V., Gatt, S., and Frankel, M.: Primary familial xanthomatosis with involvement and calcification of the adrenals. Pediatrics,
28: 274 (1961).

33. Lyosomal acid lipase is the term we have chosen to denote the enzyme which is deficient in WD and CESD. It has been variously called acid lipase $(2,13)$, acid esterase (19) and the activities measured as acid cholesteryl ester hydrolase and acid triglyceride lipase $(10,26)$.

34. Grand Island Biological Co., Grand Island, N. Y.

35. Bellco Glass, Inc., Vineland, N. J.

36. Heat Systems/Uitrasonics, Plainview, N. Y

37. Gallard-Schlesinger, Carle Place, N. Y

38. Research Products International, Elk Grove Village, III.

39. Supelco, Inc., Bellefonte, Pa.

40. Sigma Chemicals, St. Louis, Mo.

41. American Instrument Company, Silver Springs, Md.

42. Amersham-Searle Corp., Arlington Heights, Ill.

43. Packard Instrument Co., Downers Grove, Ill.

44. Kalex Scientific, Manhasset, N. Y.

45. This work was supported by General Research Support Grant, National Institutes of Health no. RR-05493; the National Institutes of Health, Maternal and Child Health Service Grant no. MCT-00417; and National Institutes of Health, National Institute of Arthritis, Metabolism and Digestive Diseases Grant no. AM-06872.

46. We thank Ms. C. Kavai, Ms. B. Marotta, and Mr. J. El-Khoury for their valuable technical assistance, Drs. Fredrickson and Sloan for the lipid and enzyme analyses of the tissues of our patient, as well as for their kindness in giving us cells from their patient with CESD, and Drs. Harry Harris, William Mellman, and Stanton Segal for reviewing the manuscript.

47. These studies were performed with the informed consent of the subjects, or in the case of children, with the informed consent of their parents.

48. The present address of Drs. J. A. Cortner and P. M. Coates is: Joseph Stokes, Jr. Research Institute, Children's Hospital of Philadelphia, 34th and Civic Center Blvd., Philadelphia, Pa. 19104.

49. The present address of Dr. E. Swoboda is: E. J. Meyer Memorial Hospital, Buffalo, N. Y. 14215

50. Requests for reprints should be addressed to: J. A. Cortner, M.D., Physician-inChief, Children's Hospital of Philadelphia, 34th and Civic Center Blvd., Philadelphia, Pa. 19104 (USA).

51. Accepted for publication May 21, 1976
Ductus arteriosus lung

fetus

foramen ovale

\title{
Positive End Expiratory Pressure (PEEP) and Right to Left Shunting in Immature Goats
}

\author{
EDMUND A. EGAN ${ }^{(27)}$ AND JACK R. HESSLER
}

Departments of Pediatrics and Comparative Medicine, University of Florida College of Medicine, Gainesville, Florida, USA

\section{Extract}

Immature fetal goats were exteriorized by caesarean section and catheters were placed in a pulmonary vein (PV), carotid artery (CA), femoral artery (FA), and the main pulmonary artery (PA). The goats were ventilated at 7.5 and $15 \mathrm{~cm} \mathrm{H}_{2} \mathrm{O}$ positive end expiratory pressure (PEEP) between control periods at 0 PEEP. Right to left shunting $\left(Q_{\mathrm{s}} / \mathbf{Q}_{\mathrm{t}}\right)$ was calculated for three anatomic sites: lung, foramen ovale, and ductus arteriosus, and for two summation shunts: preductal and total. Total $Q_{s} / Q_{t}$ increased in 8 of 14 animals at $7.5 \mathrm{~cm} \mathrm{H}_{2} \mathrm{O}$ PEEP and in 7 of 12 animals at $15 \mathrm{~cm}$ $\mathrm{H}_{2} \mathrm{O}$ PEEP. Intrapulmonary shunting increased in only one experiment. The increase in total $Q_{B} / Q_{t}$ resulted from elevated extrapulmonary shunting, always including the ductus arteriosus. The variation in response to PEEP was from animal to animal and not from one level to another within one animal. Changes in total $Q_{s} / Q_{t}$ on PEEP did not correlate with the size of control $Q_{B} / Q_{t}$ at any site.

\section{Speculation}

PEEP can simultaneously improve oxygenation of pulmonary venous blood and lower systemic oxygen content in newborn mammals with lung disease. This suggests that PEEP has important physiologic effects on distribution of the neonatal cardiopulmonary circulation. Future quantitative definitions of these relationships may improve the management of hypoxemia neonatal respiratory failure.

Positive end expiratory pressure used with positive pressure 
mechanical ventilation increases the arterial oxygen content in hypoxemia due to pulmonary disease $(16,20)$. This improvement in arterial oxygen content can be accompanied by increases in pulmonary artery pressure and increases in pulmonary vascular resistance in adult patients (20).

PEEP has also been used successfully to increase the arterial oxygen content in small newborn infants with respiratory failure $(10,11)$. However, if a significant increase in pulmonary vascular resistance occurs with PEEP, it may be critical for a newborn. The foramen ovale and ductus arteriosus are still anatomically patent, and increases in pulmonary vascular resistance could potentially worsen hypoxemia by producing venous shunting into the arterial stream at either site. We undertook to evaluate this possibility by studying the effects of PEEP in immature exteriorized fetal goats in an experimental preparation in which lung, foramen ovale, and ductus arteriosus components of venous admixture could be separated.

\section{MATERIALS AND METHODS}

Experiments were conducted on 14 fetal goats with a mean gestational age of 131 days ( 0.87 of full term) and a range of 117-150 days. Nannies were anesthetized with chloralose, the fetus exteriorized, and a closed tracheal cannula secured before any ventilation. Catheters were secured into a carotid artery, femoral artery, and a venous cannula was threaded from a femoral vein into the right atrium (RA). A left thoracotomy was performed, and a cannula was inserted through the left atrial appendage into a right pulmonary vein. In six of the animals, at the end of the experiment, the PV catheter was found malpositioned, and lying either in the right or left atrium. These six are included in the report because significant shunting could still be measured. A PA cannula was inserted by direct puncture of the main pulmonary artery and secured well proximal to the ductus arteriosus for sampling mixed venous blood.

At the start of an experiment, the umbilical cord was clamped and the animal was ventilated with a $\mathrm{F}_{\mathrm{I}} \mathrm{O}_{2}$ of 1.0 using a Harvard animal ventilator in a closed system with an $\mathrm{O}_{2}$-filled spirometer and calcium carbonate for $\mathrm{CO}_{2}$ absorption. After an initial equilibration period, the animal was ventilated for two 20 -min periods of PEEP, one at $7.5 \mathrm{~cm} \mathrm{H}_{2} \mathrm{O}$ and one at $15 \mathrm{~cm} \mathrm{H}{ }_{2} \mathrm{O}$. Each PEEP period was preceded and followed by a $20-\mathrm{min}$ period of ventilation at 0 PEEP. The order of PEEP ventilation was varied among animals. At 10 -min intervals during the experimental periods, simultaneous blood samples were drawn from PA, PV, CA, and FA for oxygen measurement and shunt calculations. Oxygen consumption (volume change in the spirometer) and electrically meaned pressure in the PA, RA, and CA were continually recorded. Because constant volume ventilation will markedly change inspiratory pressures at different values of PEEP, tidal volume was decreased and respiratory rate increased during PEEP in an attempt to hold minute volume, maximum inspiratory pressure, and $\mathrm{pCO}_{2}$ constant. These premature animals were somewhat unstable, and complete control of these variables was not attained as is shown in Table 1 .

Immature fetuses were selected to study PEEP in abnormal lungs. An estimate of surface active material in the amniotic fluid and fetal lung liquid was made for each animal by the rapid test for surfactant of Clements et al. (3). Only the animal of 150 days of

Table 1. Values of ventilation parameters (average $\pm S E$ )

\begin{tabular}{lccc}
\hline & Control & $7.5 \mathrm{~cm} \mathrm{PEEP}^{1}$ & $15 \mathrm{~cm}$ PEEP \\
\hline $\begin{array}{l}\text { Inspiratory pressure } \\
\left(\mathrm{cm} \mathrm{H} \mathrm{H}_{2} \mathrm{O}\right)\end{array}$ & $24 \pm 1$ & $25 \pm 1$ & $29 \pm 1$ \\
$\begin{array}{c}\mathrm{Minute}^{-1} \text { ventilation }(\mathrm{cc} \cdot \\
\left.\mathrm{kg}^{-1} \cdot \mathrm{min}^{-1}\right) \\
\mathrm{paCO}_{2}(\mathrm{~mm} \mathrm{Hg})\end{array}$ & $168 \pm 22$ & $179 \pm 18$ & $184 \pm 19$ \\
\hline
\end{tabular}

${ }^{1}$ Positive end expiratory pressure. gestation had a positive test on amniotic fluid and then only at a 1:1 dilution. Four other animals had a positive test on a 1:1 dilution on tracheal fluid. In humans a negative test on amniotic fluid correlates well with clinical pulmonary disease $(3,15)$, as it did in these animals whose initial control alveolar-carotid artery $\mathrm{pO}_{2}$ gradient averaged $476 \mathrm{~mm} \mathrm{Hg}$ (range of $301-612 \mathrm{~mm} \mathrm{Hg}$ ). Alveolar $\mathrm{pO}_{2}$ was estimated from the alveolar gas equation for a $\mathrm{F}_{\mathrm{I}} \mathrm{O}_{2}$ of 1.0 , a respiratory quotient of 1.0 , and a $\mathrm{pCO}_{2}$ identical with CA blood.

The immaturity of the fetal animals created an inherently unstable experimental preparation. All control values are given as the mean of the values obtained at the end of the control period immediately preceding the PEEP period and, at the end of the control period following the PEEP period. This method represents an attempt to compensate for changes which may have occurred in a ventilated, immature animal independently of the experimental protocol.

Blood $\mathrm{pCO}_{2}, \mathrm{PO}_{2}$, and $\mathrm{pH}$ were determined on an Instrument Laboratories blood gas analyzer immediately after sampling. The hematocrit was measured on each sample. Blood oxygen content was calculated using the values of Hellegers et al. (11) for a $P_{50}$ of fetal goats at $0.8-0.9$ of term as $20 \mathrm{~mm} \mathrm{Hg}$ and a correction value of $-\mathbf{0 . 6 2}$ for the Bohr effect. Hemoglobin content was calculated from the relationship: packed cell volume $/ 3=$ hemoglobin in grams/ $100 \mathrm{ml}$ from the procedure of Elliot $e t$ al. (8) for fetal goats. Since oxygen content calculated on these samples was compared only with simultaneous samples taken from other sites, significant errors which might occur from animal to animal variations in $P_{50}$ or an inconstant relationship of hemoglobin to packed cell volume were minimized. Blood volumes lost in sampling were replaced with heparinized blood obtained from the fetal side of the placenta after clamping the umbilical cord.

Calculations of right to left shunts were based on the standard shunt equation (2): $\left.\mathrm{Q}_{\mathrm{s}} / \mathrm{Q}_{\mathrm{t}}=\left(\mathrm{Ca}_{\mathrm{O}_{2}}-\mathrm{Cpv}_{\mathrm{O}_{2}}\right) / \mathrm{Cpa}_{\mathrm{O}_{2}}-\mathrm{Cpv}_{\mathrm{O}_{2}}\right)$, where $\mathrm{Q}_{\mathrm{s}}=$ shunt flow, $\mathrm{Q}_{\mathrm{t}}=$ total blood flow, $\mathrm{Ca}_{\mathrm{O}_{2}}=$ arterial oxygen content, $\mathrm{Cpv}_{\mathrm{O}_{2}}=$ pulmonary vein oxygen content, $\mathrm{Cpa}_{\mathrm{O}_{2}}=$ pulmonary artery oxygen content. This shunt equation was modified so that five specific shunts could be calculated. The $Q_{B} / Q_{t}$ was calculated for the three anatomic sites (intrapulmonary, foramen ovale, and ductus arteriosus) and for two cumulative values (preductus arteriosus and total). The definition of the shunt equation was generalized to calculate the venous admixtures at the various sites. Thus: $\mathrm{Q}_{\mathrm{s}} / \mathrm{Q}_{\mathrm{t}}=\left(\mathrm{Ct}_{\mathrm{O}_{2}}-\mathrm{Co}_{\mathrm{O}_{2}}\right) /\left(\mathrm{Cpa}_{\mathrm{O}_{2}}-\mathrm{Co}_{\mathrm{O}_{2}}\right)$, where $\mathrm{Ct}_{\mathrm{O}_{2}}=$ $\mathrm{O}_{2}$ content in $\mathrm{Q}_{\mathrm{t}}$, blood flow just distal to site shunt, $\mathrm{Co}_{\mathrm{O}_{2}}=\mathrm{O}_{2}$ content in oxygenated blood contributing to $\mathrm{Q}_{\mathrm{t}} ; \mathrm{Cpa}_{\mathrm{O}_{2}}=\mathrm{O}_{2}$ content in pulmonary artery (mixed venous) blood. Each individual shunt calculated in this manner defines the fractional dilution of arterialized blood by mixed venous blood which was shunted at the site. For example, in a single animal the pulmonary venous blood could contain $60 \%$ mixed venous blood and thus a lung $Q_{s} / Q_{t}$ of 0.6; an additional right to left shunt at the foramen ovale so that pulmonary venous blood was $40 \%$ and mixed venous blood $60 \%$ of carotid artery flow (a foramen ovale $\mathrm{Q}_{\mathrm{g}} / \mathrm{Q}_{\mathrm{t}}$ of 0.6 ); and finally, a ductus arteriosus shunt so that $60 \%$ of descending aorta flow is from the PA and $40 \%$ from the ascending aorta (a ductus $Q_{s} / Q_{t}$ of $0.6)$. However, the total shunt is not the sum of these three $(120 \%)$, but the cumulative fraction of shunting at all sites $(93 \%) . \mathrm{Q}_{\mathrm{s}} / \mathrm{Q}_{\mathrm{t}}$ must lie between 0 and 1 and is easily thought of as the total fraction of the red blood cells in mixed venous blood shunted into the site distal to the shunt which did not pass through pulmonary capillaries adjacent to ventilated alveoli.

\section{RESULTS}

Ventilation of the immature fetal goats with PEEP increased total right to left shunting $\left(\mathrm{Q}_{\mathrm{s}} / \mathrm{Q}_{\mathrm{t}}\right)$ in 8 of the 14 experiments at 7.5 $\mathrm{cm} \mathrm{H}_{2} \mathrm{O}$ PEEP, and in 7 of the 12 experiments at $15 \mathrm{~cm} \mathrm{H}_{2} \mathrm{O}$ PEEP. The higher PEEP caused sudden death in two animals (with normal blood pressures and adequate arterial $\mathrm{pO}_{2}$ ) within minutes. Table 2 summarizes the observed changes in total $Q_{B} / Q_{t}$. 
The variation was primarily between different animals rather than variation in a single experimental animal at the two different levels of PEEP. As shown in Table 3, no animal increased right to left shunting at one level and decreased it at the other, although five animals showed a change in $Q_{s} / Q_{t}$ from control at one level PEEP and no change from control $\mathrm{Q}_{\mathrm{s}} / \mathrm{Q}_{\mathrm{t}}$ at the other.

\section{PATTERNS OF RESPONSE}

The variation in $Q_{s} / Q_{t}$ produced by $P E E P$ in these immature animals is illustrated by the course of two individual animals during an entire experiment. In Figure 1, the sequential data are plotted for animal 11 in which PEEP decreased $Q_{\mathrm{s}} / \mathrm{Q}_{\mathrm{t}}$. In this animal, inability to place the pulmonary venous catheter accurately allowed calculation of preductus arteriosus, ductus arteriosus, and total shunting, but did not allow separation of the intrapulmonary and foramen ovale components of the preductus arteriosus shunt. Before PEEP, there was a $60 \%$ dilution of the oxygenated blood flow from the lungs with mixed venous blood, as sampled in the CA. A further $60 \%$ dilution of ascending aortic blood by pulmonary artery blood occurred at the ductus arteriosus. During the initial $20 \mathrm{~min}$ at $15 \mathrm{~cm} \mathrm{H} \mathrm{H}_{2} \mathrm{O} P E E P$, the total $\mathrm{Q}_{\mathrm{s}} / \mathrm{Q}_{\mathrm{t}}$ plummeted with the shunting decreasing at preductal sites and at the ductus arteriosus. During the inter-PEEP control period, total $Q_{s} / Q_{t}$ plateaued, and the ductus arteriosus shunt disappeared so that preductus arteriosus and total $\mathrm{Q}_{\mathrm{s}} / \mathrm{Q}_{\mathrm{t}}$ were identical. Ventilation for a second 20-min period with PEEP at $7.5 \mathrm{~cm} \mathrm{H}_{2} \mathrm{O}$ did not significantly change any $Q_{g} / Q_{t}$. During this second PEEP period, the systemic artery pressure decreased, although there was no change in pulmonary artery pressure.

The other pattern of response to PEEP was an increase in $\mathrm{Q}_{\mathrm{s}} / \mathrm{Q}_{\mathrm{t}}$, and this pattern is illustrated by the graphic summary of animal 13 in Figure 2. During the initial control period, small ductus arteriosus and foramen ovale shunts disappeared, and just before the application of the first period of PEEP there was a $32 \%$ right to left shunt localized exclusively to the intrapulmonary site. Application of $15 \mathrm{~cm} \mathrm{H}_{2} \mathrm{O}$ PEEP produced a large ductal shunt, a small foramen ovale shunt, and a large increase in total $Q_{s} / Q_{t}$. It is important to note that the intrapulmonary shunt decreased during

Table 2. Changes in total right to left shunt $\left(Q_{s} / Q_{t}\right)$ with positive end expiratory pressure $(P E E P)$ in immature fetal goats ${ }^{1}$

\begin{tabular}{lcc} 
& \multicolumn{2}{c}{ PEEP } \\
\cline { 2 - 3 } \multicolumn{1}{c}{ Total right to left shunting } & $7.5 \mathrm{~cm} \mathrm{H}_{2} \mathrm{O}$ & $15 \mathrm{~cm} \mathrm{H}_{2} \mathrm{O}$ \\
\hline Increased & 8 & 7 \\
No change & 3 & 2 \\
Decreased & 3 & 3 \\
Died before measurement & 0 & 2 \\
Total & 14 & 14 \\
\hline
\end{tabular}

${ }^{1}$ Increased or decreased shunting indicates a variation in $\mathrm{Q}_{\mathrm{g}} / \mathrm{Q}_{\mathrm{t}}$ of greater than 0.05 from control values.

Table 3. Correlation in responses of total right to left shunt $\left(Q_{s} / Q_{t}\right)$ to 7.5 and $15 \mathrm{~cm} \mathrm{H}_{2} \mathrm{O}$ positive end expiratory pressure $(P E E P)^{1}$

\begin{tabular}{clccc}
\hline & \multicolumn{3}{c}{$15 \mathrm{~cm} \mathrm{H}_{2} \mathrm{O}$ PEEP } \\
\cline { 3 - 5 } & & Increase & No change & Decrease \\
\hline \multirow{2}{*}{$\begin{array}{c}\text { Increase } \\
\text { PEEP H }\end{array}$} & 6 & 1 & 0 \\
& No Change & 1 & 0 & 2 \\
& Decrease & 0 & 1 & 1 \\
\hline
\end{tabular}

${ }^{1}$ Results of 12 animals studied at both levels.
PEEP even as total $Q_{s} / Q_{t}$ increased. Pulmonary artery pressure exceeded systemic arterial pressure within minutes after the PEEP was started. The interexperimental period at 0 PEEP shows the return of all parameters toward pre-PEEP values. The second PEEP period of $7.5 \mathrm{~cm} \mathrm{H}_{2} \mathrm{O}$ PEEP produced changes in all parameters similar to those observed at $15 \mathrm{~cm} \mathrm{H}_{2} \mathrm{O}$ PEEP, but to a lesser degree. In the final control period the changes persisted accompanied by systemic hypotension, indicating deterioration of the preparation. In this animal, PEEP produced a decrease in intrapulmonary shunting, but an increase in total $Q_{s} / Q_{t}$ due to increased shunting at the foramen ovale and ductus arteriosus.

\section{SITES OF SHUNTING}

The effect of each level of PEEP on $Q_{s} / Q_{t}$ at each of the three anatomic sites and on the preductus arteriosus $Q_{B} / Q_{t}$ is detailed in

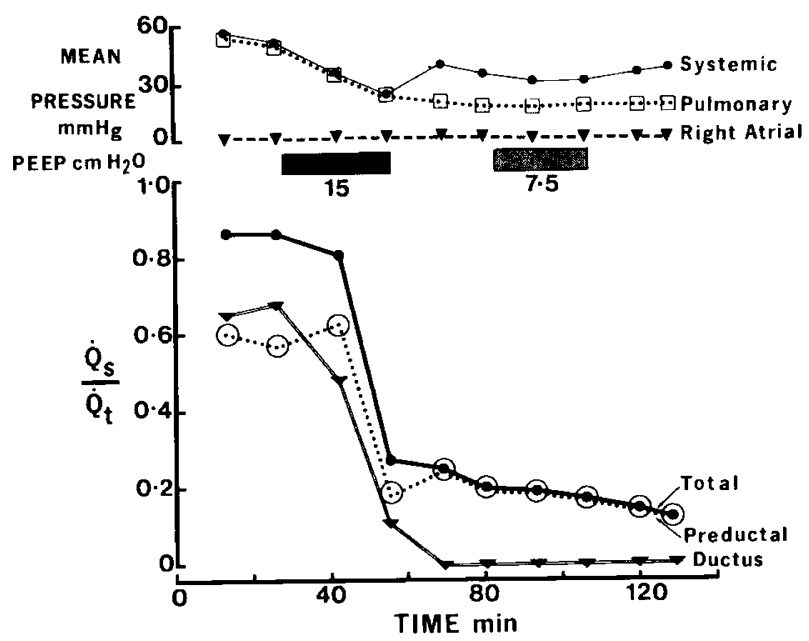

Fig. 1. Time course of Experiment 11. Top graph is electrical mean pressures in main pulmonary artery, systemic (carotid) artery, and right atrium. Lower graph traces the calculated right to left shunts (see "Materials and Methods") for total shunt (-), preductus arteriosus shunt $(\cdots)$, and ductus arteriosus shunt $(\Longrightarrow$. Solid bars detail time of positive end expiratory pressure $(P E E P)$ and its level in $\mathrm{cm}_{2} \mathrm{O}$.

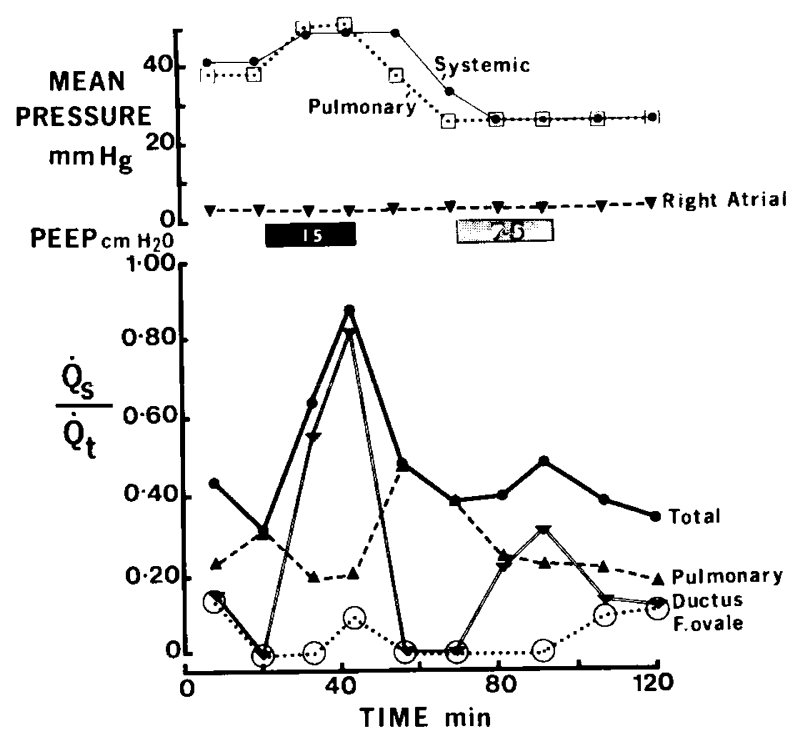

Fig. 2. Time course for Experiment 13. Top graph gives electrical mean pressures for main pulmonary artery, systemic (carotid) artery, and right atrium. Lower graph traces the calculated right to left shunts (see "Materials and Methods") for total shunt ( - ), intrapulmonary shunt $(--)$, ductus arteriosus shunt $(=)$, and foramen ovale shunt $(\cdots)$. Solid bars detail time of positive end expiratory pressure $(P E E P)$ and its level in $\mathrm{cm} \mathrm{H}_{2} \mathrm{O}$. 
Table 4. Incidence and direction of changes in total right to left shunt $\left(Q_{s} / Q_{t}\right)$ on 7.5 and $15 \mathrm{~cm} \mathrm{H}_{2} \mathrm{O}$ positive end expiratory pressure $(P E E P)^{1}$

\begin{tabular}{|c|c|c|c|c|c|c|c|c|}
\hline & \multicolumn{4}{|c|}{$7.5 \mathrm{~cm} \mathrm{H}_{2} \mathrm{O} P E E P$, variation total $\mathrm{Q}_{\mathrm{s}} / \mathrm{Q}_{\mathrm{t}}$} & \multicolumn{4}{|c|}{$15 \mathrm{~cm} \mathrm{H}_{2} \mathrm{O} P E E P$, variation total $Q_{s} / Q_{t}$} \\
\hline & $n$ & Increase & No change & Decrease & $n$ & Increase & No change & Decrease \\
\hline Intrapulmonary & 9 & 0 & 4 & 5 & 6 & 1 & 3 & 2 \\
\hline Foramen ovale & 9 & 3 & 2 & 4 & 6 & 3 & 2 & 1 \\
\hline Total preductal (PA to CA) & 14 & 6 & 4 & 4 & 12 & 6 & 2 & 4 \\
\hline Ductal & 14 & 9 & 4 & 1 & 12 & 6 & 3 & 3 \\
\hline
\end{tabular}

${ }^{1}$ A change means that the percentage of shunt on PEEP varies more than 0.05 from its average value at 0 PEEP before and after the period of elevated PEEP. PA: pulmonary artery; CA: carotid artery.

Table 5. Changes in oxygen consumption pulmonary artery to systemic artery pressure ratio $(P A P / S A P)$, and right to left shunt $\left(Q_{s} / Q_{t}\right)$ at various sites after positive end expiratory pressure $(P E E P)^{1}$

\begin{tabular}{|c|c|c|c|c|c|c|}
\hline & \multicolumn{3}{|c|}{$7.5 \mathrm{~cm}$ PEEP } & \multicolumn{3}{|c|}{$15 \mathrm{~cm}$ PEEP } \\
\hline & $n$ & Control & PEEP & $n$ & Control & PEEP \\
\hline \multicolumn{7}{|l|}{ Group I (total $\mathrm{Q}_{\mathrm{s}} / \mathrm{Q}_{\mathrm{t}}$ increased) } \\
\hline $\mathrm{O}_{2}$ consumption $\mathrm{ml} \cdot \mathrm{kg}^{-1} \cdot \min ^{-1}$ & 7 & $5.30 \pm 0.50$ & $4.7 \pm 0.40^{2}$ & 6 & $5.30 \pm 0.50$ & $4.30 \pm 0.50$ \\
\hline PAP/SAP & 8 & $0.90 \pm 0.05$ & $1.05 \pm 0.04^{3}$ & 7 & $0.74 \pm 0.07$ & $0.93 \pm 0.06^{3}$ \\
\hline$Q_{s} / Q_{t}$, lung & 4 & $0.21 \pm 0.04$ & $0.19 \pm 0.03$ & 3 & $0.20 \pm 0.08$ & $0.16 \pm 0.03$ \\
\hline $\mathrm{Q}_{\mathrm{s}} / \mathrm{Q}_{\mathrm{t}}$, foramen ovale & 4 & $0.05 \pm 0.05$ & $0.10 \pm 0.05$ & 3 & $0.04 \pm 0.03$ & $0.28 \pm 0.10$ \\
\hline $\mathrm{Q}_{\mathrm{s}} / \mathrm{Q}_{\mathrm{t}}$, preductus arteriosus & 8 & $0.29 \pm 0.05$ & $0.33 \pm 0.09$ & 7 & $0.25 \pm 0.04$ & $0.55 \pm 0.09^{2}$ \\
\hline $\mathrm{Q}_{\mathrm{s}} / \mathrm{Q}_{\mathrm{t}}$, ductus arteriosus & 8 & $0.18 \pm 0.07$ & $0.45 \pm 0.07^{3}$ & 7 & $0.23 \pm 0.11$ & $0.59 \pm 0.11^{2}$ \\
\hline \multicolumn{7}{|l|}{ Group II (total $\mathrm{Q}_{\mathrm{B}} / \mathrm{Q}_{\mathrm{t}}$ not increased) } \\
\hline $\mathrm{O}_{2}$ consumption $\mathrm{ml} \cdot \mathrm{kg}^{-1} \cdot \mathrm{min}^{-1}$ & 6 & $5.10 \pm 0.90$ & $4.60 \pm 0.70$ & 5 & $5.50 \pm 0.90$ & $5.90 \pm 1.50$ \\
\hline PAP/SAP & 6 & $0.67 \pm 0.07$ & $0.72 \pm 0.06$ & 5 & $0.82 \pm 0.13$ & $0.90 \pm 0.09$ \\
\hline $\mathrm{Q}_{\mathrm{s}} / \mathrm{Q}_{\mathrm{t}}$, lung & 5 & $0.34 \pm 0.08$ & $0.20 \pm 0.07^{2}$ & 3 & $0.34 \pm 0.21$ & $0.24 \pm 0.12$ \\
\hline $\mathrm{Q}_{\mathrm{s}} / \mathrm{Q}_{\mathrm{t}}$, foramen ovale & 4 & $0.10 \pm 0.06$ & $0.11 \pm 0.05$ & 3 & $0.21 \pm 0.17$ & $0.12 \pm 0.10$ \\
\hline $\mathrm{Q}_{\mathrm{B}} / \mathrm{Q}_{\mathrm{t}}$, preductus arteriosus & 6 & $0.35 \pm 0.09$ & $0.26 \pm 0.08^{2}$ & 5 & $0.49 \pm 0.17$ & $0.39 \pm 0.16$ \\
\hline $\mathrm{Q}_{\mathrm{s}} / \mathrm{Q}_{\mathrm{t}}$, ductus arteriosus & 6 & $0.18 \pm 0.11$ & $0.13 \pm 0.09$ & 5 & $0.20 \pm 0.09$ & $0.15 \pm 0.12$ \\
\hline
\end{tabular}

\footnotetext{
${ }^{1}$ Values are given as means \pm SE. Significance levels calculated from the paired $t$-test.

${ }^{2} P<0.05$.

${ }^{3} P<0.01$.
}

Table 4. In the 15 periods of PEEP in which intrapulmonary shunting was measured, it increased in only one instance. On the other hand, $Q_{B} / Q_{t}$ changes at the other sites were more variable.

\section{QUANTITATIVE RESPONSES TO PEEP}

We divided the experiments into two groups by the change in total $Q_{s} / Q_{t}$ in order to demonstrate the two patterns of response to PEEP observed. Group I consists of those animals in whom PEEP produced an increase in total $\mathrm{Q}_{\mathrm{s}} / \mathrm{Q}_{\mathrm{t}}$ of more than 0.05 , and Group II consists of those animals in whom total $\mathrm{Q}_{\mathrm{s}} / \mathrm{Q}_{\mathrm{t}}$ on PEEP did not change or decreased. Table 5 summarizes the data by groups. The arterial pressures are expressed as the ratio of pulmonary artery pressure to systemic artery pressure (PAP/SAP) rather than absolute values because of the animal to animal variation and because in an individual experiment, presence of right to left shunting at extrapulmonary sites will correlate closely with their relative values.

The animals in group $I$ showed a significant elevation of the PAP/SAP ratio, a decrease in oxygen consumption, and increase in $Q_{\mathrm{a}} / \mathrm{Q}_{\mathrm{t}}$ at the ductus arteriosus at both levels of PEEP. In addition, preductal $\mathrm{Q}_{\mathrm{s}} / \mathrm{Q}_{\mathrm{t}}$ significantly increases at $15 \mathrm{~cm} \mathrm{H} \mathrm{H}_{2} \mathrm{O}$ PEEP, probably because of foramen ovale shunting. The pattern of changes in this group all appear secondary to shunting a fraction of systemic venous return through the ductus arteriosus.

In group $I I$, the only significant change in any parameters at either PEEP was a decrease in lung and preductus $Q_{s} / Q_{t}$ at $7.5 \mathrm{~cm}$ PEEP.
An analysis of factors that might predict the response to PEEP was unrewarding. Neither initial total $Q_{s} / Q_{t}$ nor initial $Q_{s} / Q_{t}$ at any site correlated with the change in total $Q_{s} / Q_{t}$ at either level of PEEP. The five animals with detectable surface active substances in fetal lung liquid fell into both groups. In Table 5 at $7.5 \mathrm{~cm}$ PEEP the control PAP/SAP ratio is significantly higher in Group $I$ than group $I I(0.05>P<0.01)$. However, no such difference was seen at $15 \mathrm{~cm} \mathrm{H}_{2} \mathrm{O}$ PEEP.

\section{DISCUSSION}

Neonatal animals change from a parallel fetal cardiopulmonary circulation to a series adult circulation because of the decrease in pulmonary resistance which occurs with the first aeration of the lungs at the onset of breathing $(4,6)$. Physiologic reversal of fetal right to left shunting at the ductus arteriosus and at the foramen ovale is secondary to this decrease in pulmonary blood flow. Anatomic closure of both of these potential shunts takes days in full term neonates (9) and much longer in immature, sick neonates (17). Until anatomic closure occurs, these shunts are potentially reversible, particularly in view of the relatively high "normal" pulmonary pressures in the immediate postnatal period (19). PEEP characteristically increases pulmonary resistance in animals with normal lungs (18), experimentally diseased lungs (14), and clinically diseased lungs $(20)$ even if it lowers $Q_{s} / Q_{t}$. This effect will not have a major influence on tissue oxygen delivery in the adult circulation unless there is a significant decrease in total cardiac output. However, in immature neonatal animals with a 
potentially parallel circulation, if PEEP elevates pulmonary resistance above systemic resistance, $Q_{\mathrm{s}} / \mathrm{Q}_{\mathrm{t}}$ will increase because of shunting at extrapulmonary sites.

Right to left shunting at the ductus was the universal finding in all of our animals in which total $Q_{\mathrm{B}} / \mathrm{Q}_{\mathrm{t}}$ increased during PEEP. Foramen ovale shunting was more variable but was an important factor in increases in $Q_{s} / Q_{t}$ in some of our animals, despite the fact that no pressure rise was seen in the right atrium. This is not unexpected since large right to left atrial shunts are normal in fetal mammals and occur with very small pressure differences between left and right atria (7). The PEEP-induced atrial shunts appear to be secondary to a decrease in pulmonary venous return, for all occurred concomitantly with significant shunts at the ductus arteriosus.

Neither pulmonary vascular resistance nor changes in resistance could be measured in these animals. Either pressure or flow must be held constant to accurately measure pulmonary vascular resistance since there is not a single pressure flow function but many. However, if the ductus arteriosus is widely patent, ductus $Q_{B} / Q_{t}$ will quantitatively reflect the pulmonary/systemic resistance ratio when pulmonary resistance exceeds systemic resistance. In these open chest animals, PEEP could not directly affect systemic venous return and thus systemic resistance, so that the increases in ductus $Q_{s} / Q_{t}$ almost certainly are due to an increase in pulmonary resistance.

We hypothesize that PEEP raises pulmonary resistance primarily in alveolar units which are well ventilated. The relationship of pulmonary resistance and lung volume has been studied by Thomas et al. (21). Increases in the volume of gas in ventilated areas of the lungs in adult animals cause elevations in pulmonary vascular resistance which can be plotted as a function of the degree of inflation. Since PEEP will increase the deflation volume of ventilating units compared with 0 PEEP, an increase in vascular resistance may occur. Accentuation of this effect of lung inflation on pulmonary vascular resistance is reported at low pulmonary blood flows (22).

The heterogeneous response of total $Q_{a} / Q_{t}$ to PEEP in these immature goats probably reflects the fact that pulmonary vascular resistance is determined by more than one physiologic variable which can be affected by PEEP. Total pulmonary vascular resistance is the summation of the individual vascular resistances in each of the parallel vascular pathways between the main pulmonary artery and the left atrium, and from the law of parallel resistances equals: $1 / R_{L}=1 / R_{1}+1 / R_{2} \ldots 1 / R_{N}$, where $R_{L}$ is the total lung vascular resistance and $R_{1}, R_{2} \ldots R_{N}$ is the resistance in each of the parallel vascular pathways. In each of these pathways major factors determining the resistance are alveolar gas tensions (13) and lung inflation. PEEP, or other techniques for maintaining a continuous distending airway pressure, recruit new airspace to ventilation $(1,5,10,12)$ and improve oxygenation in areas of very low ventilation/perfusion ratios $\left(\mathrm{V}_{\mathrm{a}} / \mathrm{Q}\right)(5)$. The resulting increase in $\mathrm{pO}_{2}$ in both areas will tend to lower vascular resistance. PEEP will also increase the mean inflation of all ventilated areas of the lung (1), which may increase the local vascular resistance in these areas. In an individual animal with lung disease, the net change in total pulmonary vascular resistance will depend on whether the change in alveolar gas tensions and recruitment of air spaces to ventilation or hyperinflation of ventilated air spaces is quantitatively more important.

Although total $Q_{s} / Q_{t}$ increased in many animals, the lung $Q_{s} / Q_{t}$ was independent of changes in total right to left shunting and rose in only 1 of 15 experiments in which it was measured. Lung $Q_{s} / Q_{t}$ is presumably the fractional pulmonary blood flow perfusing atalectatic or hypoxic areas of the lung and is determined by the percentage of the airspace not involved in ventilation and the relative vascular resistances in the effectively ventilated and nonventilated areas. In those animals in which PEEP increased total $Q_{s} / Q_{t}$ but not lung $Q_{s} / Q_{t}$, the increase in the percentage of the lung effectively ventilated on PEEP appears to have counter- balanced any increased vascular resistance in ventilating areas due to inflation effects.

These experiments point to a potentially adverse effect that continuous distending airway pressure may have on arterial oxygen content in immature animals. These animals were open chest preparations and were ventilated at arbitrary levels of PEEP for short periods of time, and obviously the results cannot be directly extrapolated to the clinical setting. However, PEEP did increase fetal extrapulmonary shunts in some animals and not in others. This observation may have relevance in the use of continuous distending airway pressure therapy in newborns.

\section{SUMMARY}

Immature fetal goats were ventilated at 7.5 and $15 \mathrm{~cm} \mathrm{H} \mathrm{H}_{2} \mathrm{O}$ of PEEP and the right to left shunting $\left(Q_{s} / Q_{t}\right)$ compared with 0 PEEP levels. A heterogenous response in total shunting occurred. In the 15 of 26 experiments where total $Q_{s} / Q_{t}$ increased, the site of shunting was extrapulmonary, always through the ductus arterious, and, in some animals, also through the foramen ovale. Lung $\mathrm{Q}_{\mathrm{s}} / \mathrm{Q}_{\mathrm{t}}$ increased in only 1 of the experiments in which it was measured, and was independent of total $Q_{s} / Q_{t}$. Lung inflation effects of PEEP can significantly affect pulmonary vascular resistance, and increase extrapulmonary shunting in newborn mammals.

\section{REFERENCES AND NOTES}

1. Bancalari, E., Garcia, O. L., and Jesse, M. J.: Effects of continuous negative pressure on lung mechanics in idiopathic respiratory distress syndrome. Pediatrics, 51: 485 (1973).

2. Berggren, S. M.: The oxygen deficit of arterial blood caused by non-ventilating parts of the lung. Acta Physiol. Scand. Suppl., 11: 7 (1942).

3. Clements, J. A., Platzker, A. C. G., Tierney, D. F., Hobel, C. J., Creasy, K., Margolis, A. J., Thibeault, D. W., Tooley, W. H., and Oh, W.: Assessment of the risk of the respiratory-distress syndrome by a rapid test for surfactant in amniotic fluid. N. Engl. J. Med., 286: 1077 (1972).

4. Cook, C. D., Drinker, P. A., Jacobson, H. N., Levison, H., and Strang, L. B.: Control of pulmonary blood flow in the foetal and newly born lamb. J. Physiol., 169: 10 (1963).

5. Corbet, A. J. S., Ross, J. A., Beaudry, P. H., and Stern, L.: Effect of positive pressure breathing on $\mathrm{aADN}_{2}$ in hyaline membrane disease. J. Appl. Physiol., 38: 33 (1975)

6. Dawes, G. S.: Foetal and Neonatal Physiology, (Yearbook Medical Publishers, Inc., Chicago, 1968).

7. Dawes, G. A., Mott, J. C., and Widdicombe, J. D.: Closure of the foramen ovale in newborn lambs. J. Physiol. 128: 384 (1955).

8. Elliot, R. H., Hall, F. G., and Huggett, A. St.G.: The blood volume and oxygen capacity of foetal blood in the goat. J. Physiol., 82: 160 (1934).

9. Gessner, I., Krovetz, L. J., Benson, R. W., Prystowsky, H., Stenger, V., and Eitzman, D. V.: Hemodynamic adaptations in the newborn infants. Pediatrics, 36: 752 (1965).

10. Gregory, G. A., Kitterman, J. A., Phibbs, R. H., Tooley, W. H., and Hamilton, W. K.: Treatment of the idiopathic respiratory-distress syndrome with continuous positive airway pressure, N. Engl. J. Med., 284: 1333 (1971).

11. Hellegers, A. E., Meschia, G., Prystowsky, H., Wolkoff, A. S., and Barron, D. H.: A comparison of the oxygen dissociation curves of the bloods of maternal and fetal goats at various pH's. J. Exp. Physiol., 44: 215 (1959).

12. Herman, S., and Reynolds, E. O. R.: Methods for the improving oxygenation in infants mechanically ventilated for severe hyaline membrane disease. Arch. Dis. Childhood, 48: 612 (1973).

13. Hyman, A., and Kadowitz, P. J.: Effects of alveolar and perfusion hypoxia and hypercapnea on pulmonary vascular resistance in the lamb. Amer. J. Physiol. 282: 397 (1975).

14. Jones, R. L., and King, E. G.: Evaluation of positive end-expiratory pressure in hypoxemic dogs. J. Appl. Physiol., 35: 213 (1973).

15. Keniston, R. C., Pernoll, M. L., Buist, N. R. M., Lyon, M., and Swanson, J. R.: A prospective evaluation of lecithin/sphingomyelin ratio and the rapid surfactant test in relation to fetal pulmonary maturity. Amer. J. Obstet. Gynecol., 121: 324 (1975).

16. King, E. G., Jones, R. L., and Patakas, D. A.: Evaluation of positive end-expiratory pressure therapy in the adult respiratory distress syndrome. Can. Anaesthesiol. Soc. J., 20: 546 (1973).

17. Kitterman, J. A., Edmunds, L. H., Jr., Gregory, G. A., Heyman, M. A., Tooley, W. H., and Rudolph, A. M.: Patent ductus arteriosus in premature infants: Incidence, relation to pulmonary disease and management. N. Engl. J. Med., 287: 473 (1972)

18. Lenfant, C., and Howell, B. J.: Cardiovascular adjustments in dogs during continuous pressure breathing. J. Appl. Physiol., 15: 425 (1960).

19. Rudolph, A. M., Auld, P. A. M., Golinko, R. J., and Paul, M. H.: Pulmonary vascular adjustments in the neonatal period. Pediatrics, 36: 763 (1965). 
20. Suter, P. M., Fairley, H. B., and Isenberg, M. D.: Optimum end-expiratory airway pressure in patients with acute pulmonary failure. N. Engl. J. Med., 292: 284 (1975).

21. Thomas, L. J., Griffo, Z. J., and Roos, A.: Effect of negative-pressure inflation of the lung on pulmonary vascular resistance. J. Appl. Physiol., 16: 451 (196I).

22. Whittenberger, J. L., McGregor, M., Berglund, E., and Borst, H. G.: Influence of state of inflation of the lung on pulmonary vascular resistance. J. Appl. Physiol., 15: 878 (1960).

23. The authors thank Ms. Valerie Cole and Ms. Nancy Miller for excellent technical assistance.
24. Some of these data were presented at the 1975 Southern Society for Pediatric Research meetings.

25. This research was supported by National Grants HI-16864-01 and H1-13749-05, and by cooperative funds of the Florida Heart Association and its chapters.

26. The current address of Dr. J. R. Hessler is: University of Tennessee Medical Center, Memphis, Tenn.

27. Requests for reprints should be addressed to: E. A. Egan, M.D., Department of Pediatrics, Box J-296, University of Florida College of Medicine, Gainesville, Fla. 32610 (USA)

28. Accepted for publication May 25, 1976.

\title{
Growth and Nutrition of Uremic Piglets
}

\author{
P. R. BETTS, ${ }^{(23)}$ M. D. MANN, AND J. WOLFSDORF \\ Department of Paediatrics and Child Health, University of Rhodesia, Salisbury, Rhodesia
}

\section{Extract}

Piglets aged 6 days were rendered uremic by subtotal nephrectomy and their growth and dietary intakes studied over the next 21 days. Eleven control piglets fed a voluntary intake of a sow's milk substitute (group $A$ ), 11 nephrectomized piglets fed a voluntary intake of the same feed ( $g$ roup $B$ ), 6 nephrectomized piglets tube fed the same milk (group $C$ ), and 11 nephrectomized piglets fed a voluntary intake of a low protein, isocaloric food (group $D$ ) were studied. After nephrectomy the piglets had an initial rapid rise in blood urea concentration which had fallen by day 7 and then leveled out around $13 \mathrm{mmol} /$ liter in group $B$ and $8 \mathrm{mmol} /$ liter in group $D$.

After operation control piglets (group $A$ ) ate more from day 4 and were larger from day 7 than the nephrectomized piglets (group $B$ ). Those piglets tube fed ( $g r o u p C$ ) were of a similar size to the controls but all died between day 7 and day 11 with associated high blood urea concentrations. Piglets fed the low protein, isocaloric feed ( $g r o u p D$ ) were smaller than both the controls and group $B$. They also ate less food than the controls and those nephrectomized piglets in group $B$ which were on a voluntary intake of the normal feed.

\section{Speculation}

Reduced energy intake is related to growth retardation seen in children with chronic renal insufficiency. However, is this the cause or result of reduced growth velocity? Ensuring a satisfactory intake of energy and nutrients from birth may ensure an initial normal growth pattern in children with chronic renal insufficiency.

Short stature is a well recognized consequence of chronic renal insufficiency in childhood $(2,3,16)$. Reduced growth velocity occurs predominantly on presentation in infancy, and in later childhood when it is associated with the terminal stages of the disease (2). Most studies have concentrated on children in their terminal stage of disease and have shown that a reduced caloric intake is a major factor in this growth retardation $(3,16)$. In an animal model, Chantler et al. (4) have demonstrated both reduced growth and dietary intake in weaned rats after subtotal nephrectomy resulting in blood urea concentrations equivalent to severe renal failure.

Infants with renal insufficiency may have a rapid fall in weight centile over the first few months of life, with little evidence of subsequent catch-up growth (2). If this fall can be shown to be due primarily to calorie deficiency, then prevention at this stage may be possible by dietary means. The piglet may be a suitable animal model on which to study growth patterns in infancy. These animals have a rapid growth rate increasing from $1.5 \mathrm{Kg}$ at birth to $90 \mathrm{Kg}$ by 6 months of age when they are sexually mature. They can also be successfully fed from soon after birth on artificial milk, having first received colostrum. Furthermore, many aspects of renal physiology in the piglet are similar to those of the infant $(11,12)$.

The present study was undertaken in order to determine the growth and dietary intake of piglets rendered uremic in the first week of life and studied until age 1 month. The first part of the study compared the growth and voluntary intake of a sow's milk substitute of piglets rendered uremic by partial nephrectomy with values for healthy piglets. The second part of the study was an attempt to obtain normal growth by feeding nephrectomized piglets the same amount of milk as the controls had taken. In the third part of the study the growth of nephrectomized piglets was measured on a voluntary intake of an isocaloric, low protein feed, which is an analgous situation to some of the low protein feeds given in renal failure.

\section{METHODS}

Large White/Landrace cross piglets were taken from the sow at 6 days of age. Only male piglets were used because of the known difference in blood urea concentrations between the sexes (17). There were four groups: group $A$, controls (normal feed); group $B$, renals (normal feed); group $C$, renals (tube fed); and group $D$, renals (low protein feed). They were anesthetized with intraperitoneal sodium pentobarbitone $(20 \mathrm{mg} / \mathrm{kg})$ and the abdomen was opened by a left paramedian incision. Animals were made uremic 